\title{
IV.-DISCUSSION.
}

\section{IN THE MATTER OF PERSONAL. IDEALISM.}

THE present article takes its occasion from two very different events - the review of my Limits of Evolution by Mr. McTaggart in the July number of MIND, and the publication, soon afterwards, of the volume entitled Personal Idealism, by eight members of the University of Oxford. By the former, I am moved to say some things that I now discover to be very much needed for making my own position in philosophy clearer than my reviewer seems to have found it ; by the latter, I am stirred to express what I must frankly admit are "very micgled feelings" indeed.

As to the essays by the Oxford Eight, one whose fortune it had been to pat before the public some fifteen months earlier a theory bearing the same title of "Personsl Idealism" might naturally be expected to greet with lively interest the announcement of a second book under that rubric; especially, a book issuing from the English sest of philosophy justly most venerated. This lively interest I have certainly felt, and I have accordingly turned upon the contents of the new volume, not merely with curiosity, but rather with the esrnest hope of finding weighty suxiliaries for views which I count to be so inwrought with our greatest human concerns. I come back from the reading, in part fortified and encouraged, but in part, I fear in greater part, surprised and disappointed. I had supposed, of course, that the cardinsl features of the system of Personal Idealism would be agreed about and accepted, if the title was accepted which had been chosen for it by its author. It is the adoption of the title in spite of rejecting essentials in the system, that surprises and in some messure discomposes me: and all the more when one finds his own lines of division for the discussion, and even his own topical titles, running through the book. It is because I hope to prevent misunderstandings on the part of the public, and to forestall a confusion of ideas in presence of an identical name used to cover very different conceptions, dealt with, above all, by very different methods, that I am prompted to comment on the Oxford volume, and to point out some of the more important divergencies between its conception of Idealism and that which I would call Personal. 
That the book has great worth of matter, and will have much weight in the doctrinal controversy that is now upon us, follows of course from the known training and culture of its writers. In many regards, those who are in earnest about a polemic against the current anti-personal philosophies, monisms of one sort or nother, may unquestionably rejoice in its courageous, outspoken, and resouroeful assanlt apon Naturalism and Absolutism alike. And if one were to decide upon the philosophical mesning of a movement solely by the general aim of it, in disregard of its method, there would be little or nothing in the programme set forth by the Oxford Eight to which any ideslist could demur. "The reality of buman freedom, the limitations of the evolationary hypothesis, the validity of the moral valuation, and the justification of that working enthusiasm for idesls which Naturalism . . . must deride 8s a generous illusion"--this unquestionably sums up well the cause for which every idealist works; nor could anything much better express the object with which my own volume was prepared. But ono doesn't become an idealigt simply hy attachment to ideals, or by opposition to those aspects of Naturalism which assail the credit of ideals; otherwise many an empirıcist, many a positivist even, might be called an idealist, and such a persistent railer at Idealism and all its ways as Prof. James might still rank as an idealist of idealists. Idealism is constituted by the melaphysical value it sets upon ideals, not by the asthetic or the ethical, and rather by its method of putting them on the throne of things then by the mere intent to have them there. It is always distinct from Mysticism (which at the core is Emotionalism), and still more from Voluntarism. Its method is, at bottom, to vindicate the human ideals by showing them to be not merely idesls but reslities, and to effect this by exhibiting conscious being as the only absolute reality; this, again, it aims to accomplish by setting the reality of conscious being in the anly transeubjective aspect thereof, namely, in intelligence.

So the fact comes about that Idealism gets its essential character from its discovery that intelligent certainty depends on such an interpretation of reality as makes the knowledge of reality by the spontaneous light of intelligence conceivable; in short, that Idealism is necessarily Rationalism, or implies an apriorist Theory of Knowledge. No sort of Experientialism, so far as it is consistent, can rightly be called Ideslism. Voluntarism, emotive Mysticism, it readily may be, but then it is simply Subjectivism; and if it be teken in cognitive terms, it cannot get beyond Bensationism, unable as it is to provide for any changeless and universal idess with which to organise experiences into objects that are inslterably the eame for all subjects and therefore abidingly real. Not even suah a theory as Berkeley's (to whioh one of the eight esseyists sppesirs to hold, with some added helps from Kant) can be oonsistently called Idealism; for though it teaches that there is an immutable principle at the basis of our experienoes, namely the 
operation of the eternal ideas in the Divine intelligence, controlling God's communication of sensetions to us, yet the assumption of this Divine Mind is unwarranted by the strict Experientialiam from which the theory takes its departure.

One might have supposed that all this was settled beforehand, from the time of Locke. But in spite of its title, we find in the Oxford volume Experientialism running at large and everywhere: we find, in fact, (1) empiristio epistemology, (2) an organised new assault upon a priori cognitions, (3) a voluntarism of the most pronounced order, (4) ethical mystiosm combating the mysticism of the intelleot, and, finally, (5) a quasi-personalism resting upon the wholly experiential and purely temporal existence of conscious "individusls" added 88 a sooiety to his own eternal being by the creative fiat of God. In short, not a single trait of systematic Idealism is present; the heart of real individuality, of real personality, is not reached, nay, even the serious attempt to reach it is foregone; yet the whole is brought under the name of Personal Idealism. The force of misnomer could hardly farther go.

One good, however, we shall in all probability reup out of the issuance from Oxford of a co-operative book with this title, and with the contents embraced : the attention of all the thoughtful in the English-spesking world, and even far beyond it, will now surely be drawn to the vital questions involved. Thence it may be hoped that the genuine idealistic implications of froedom, of evolutional limits, of valid moral valuation, and of justified enthusissm for the ideal, will more and more clearly come into view. Not until this occurs, certainly, shall we get finslly rid of those plausible makeshifts in the way of philosophy that leave our chief ideal interests still at risk, and 80 only serve to prolong the wesry procession of philosophic disputes.

But I must pass on to deal more directly with my own attempt at contributing to this idealistio quest, and with Mr. MoTaggart's very suggestive review of my book. I am much indebted to my reviewer for the care and the penetration with which he has considered my theory; and yet I notice some important respects in which he has failed to teke my meaning. These I must set forth with all possible clesrness, in the hope of preventing further misunderstanding; and then I shall have to reply to the objections whiah he raises (or, perhaps rather, the difficalties which he suggests) in connexion with my view.

Judging by his other published writings, as well as by his review, I may fairly assume that Mr. McTaggart is in agreement with me in holding to an idealistic Pluralism, an eternal Society of many minds, esch sbsolutely resl. It is well to note, in setting out to comment on his criticisms, that there is a head under which his 
views and mine might be correctly brought into collocation with the views of our Oxford colleagues, with those of Prof. James, and even with those of more pronounced individualists, - I mean the head of Pluralism : in one way or another, we all hold out for manifold realities that are all alike indisputable. But only some of us set this Pluralism forth by an ideslistic method, and hence arrive at what we call the "eternity" of the many minds. By this we mean simply their absolute reality, or the self-based, self-active nature of their being, - nothing else at all, except as something else may be implied by this absoluteness ; least of all, do we mean merely the everlastingness, their existence "from all eternity," as the common saying is. Our doctrine has nothing whatever to do with the superstition, born of fancy, about pre-existence. In this matter I suppose Mr. McTaggart to be in entire accord with me, and I am therefore somewhat surprised to note in his review certain misapprehensions of my position. These I will now specify.

(1) He snaks of my doctrine that only an eternal being can really be free, as a "remark". This language is seriously misleadlng; the reader must surely get from it the impression that my statement of this view is merely incidental and by-the-way. On the contrary, it is in fact basic and central to the whole theory of my book, is developed with emphatic prominence, and is argued out with much detail. (Bee my pp. 326-343.)

(2) A more importent misepprehension is this: "It [the system of Personal Idealism] offers a God of whom personality, morality, and affection reasonably be predicated, since, though perfect, he is finite. (I am not sure if Dr. Howison would accept the word finite, but in effect, it seems to me, he holds God to be finite, since he makes him one of a community of spirits, each of whom has ' a reality as inexpugnable as his own '.)" "Indeed I do not accept the word, nor can. I am surprised that my real view in this matter should have escaped Mr. McTaggart. So far from bolding God to be finite, I hold, and in my book clearly teach, that all minds are infinite (in the true qualitative sense of the word), and God pre-eminently so. (See my pp. 330 seq., 363, and 373). Eternity, self-eristence, self-activity, freedom, and infinity, are to me all interchangeable terms, and are so trested wherever they turn up in the course of my book. My reviewer falls into a non sequitur when he concludes that I make God finite because I make him one of a community of spirits, each absolutely real; not God's finitude, but his definiteress, is what follows from that. This confusion of the definite with the finite is very common, and is the explanation of two tendencies in sceptical thinking-the tendency to deny the personslity of God, whose infinity is supposed to mean bis utter indefiniteness, and the tendency, in recoil from the former, to essert God's finitude in order to seve his personality, which of course must be definite. But the true infinite, as distinguished from the pseudo-infinite, the infinite of quality in 
contrast to the infinite of quantity, is entirely definite; more definite, indeed, than any finite can be.

(3) Mr. McTaggart misconstrues my various statements about the imperfection in all spirits other than God. He supposes me to hold this imperfection to be incompatible with their being perfect in any sense whatever, and he mildly blames me for overlooking the classic distinction between the view sub specie aterni and the view sub specie temporis, whereby the seeming contradiction involved in an imperfect-perfect might be reconciled. But my actual doctrine about the spirits other than God is exactly his own. "Sub specie aternitatis, every self is perfect; sub specie temporis, it is progressing towards a perfection as yet unattained," he says. And the very quotation from me on which he bases his criticism (see my p. 363) expresses this, almost in open words: "The personelity of every soul lies precisely in the relation . . . between that genuine infinity (self-ectivity) which marks its organising essence, and the finitude . . . to which the infinity [only another name for perfection] subjects itself in detining itself from God." So, too, though more explicitly, when I say (p. 374): "The perfection of the 'creature 'lies just in this never-ending process of victory. ... Thus its life shows its peculiar perfection by the mode in which ... it surely, though slowly and with heavy toil, heals its own inherent wound." And yet again: "The infinity of the 'creature,' the infinity that embosoms finitude and evermore raises this toward likeness with the eternal".

There are sundry other passages in my concluding essay that effirm the distinction drawn by Mr. McTaggart between the complete self-adequacy of the spirit as a whole in eternity and the inadequacy of it as broken up in a time-process and engaged in a perpetual struggle to attain conformity with that eternal wholeness. In fact this distinotion furnishes the whole besis for my reply in that essay to Prof. James's Dilemma of Determinism. I am really quite at one with Mr. McTaggart in what he says about the perfection of all eternal beings, in so far as they are eternal. I bave usually aroided the explicit use of the word, because it is in many contexts misleading, and also because the too free use of it would engender prejudice in most readers, thus preventing the proper appreciation of the arguments offered for the world of real freedom. That world as I intend it, and habitually think it, answers to the principles of unity and harmony quite as Mr. MoTaggart suggests.

Accordingly, my argument for the existence of God is not reached by those of his suggested objections which are founded on his assumption that I bold all minds but God to be utterly and totally imperfect, without any aspect of perfection at all. On the contrary. I hold, with him, that all eternal beings are perfect, each in its own way. But the way of God, I maintain, is the way of alisolute perfection, which eternally excludes dofect; whereas the way of every other mind is the way that includes defect, comes (or inay come) to include sin, and only exhihits its perfection in its power to return to wholeness through the process of time. 
That I have chiefly dwelt on perfection and imperfection as respectively the attributes of God and of the non-divine minds, without entering into the subtle distinction between kinds of perfution, is indèed a fact, but it should be regarded as a rhetorical ruther than a philosophical procedure. That is to say, my book was aimed at readers of general cultivation rather than at metephysical experts, and so I thought I should carry my new argument for the reality of God more surely home if I kept out of the region of the supersubtile, and relied upon those aspects of the difference between God and other minds which are the most obvious. The point of my argument, in this connexion, is that in God there is a perfection in which there is no imperfection at all, while in every other mind imperfection is present, though andergoing an endless process of cancellation. Of course, subtly analysed, this last means a species of perfection. But again my point is, that the sole possible besis for species in perfection is, primsrily, the contrast between absolute perfection (excludent of imperfection) and perfection that embraces and proceeds to reduce imperfection; and, nert, the manifold modes of which this seoond species is suscoptible, resting on what I heve called (seo my pp. 363,374 ) the "rate" of adjustment between the infinite (or perfect) and the finite (or defective) sspects of the mental being.

(4) In connexion with my argument for the existence of God, Mr. MoTaggart makes this statement: "Among the different grades [of intelligent beings] which . . . are really possible . . . Dr. Howison assumes that the highest grade of all-that of the ideal Type-is one, and consequently that a being exists who realibes the $T_{y}$ pe. So far as I can see, he does not attempt to prove this." Just what Mr. McTaggart means by his word " this,", I am in some doubt-whether be is referring to my "assuming" that the ideal Type is one of the different grades of being that are really possible, or to my taking as a direct consequence of this the actual existence of the ideal Type.

As for the first of these matters, it is not true that I assume the idesa Type to be one of the really possible intelligences; on the contrary, I show (see my pp. 353-355) that this Supreme Instance of the intelligent nature present in sll possible minds is the one salient certainty in our conception of the whole series, when we vicw the series as conceivable simply: whaterer we can not tell about the series, or the numbers in it, what we do see, and see clearly, is that it must contain, as a possibility, this Type; this I trest as the implication in the entire process of definition by which other members in the series are determined.

And as for the second point, I do not conclude to the actual existence of the divine Type directly from its ascertained possibilify; that would be merely repeating the thrice-buried Ontologic Proof over again, and the futility of that I have dwelt upon in my pp. 357-358. The identification of the divine Type as a necessary member of the conceivable series proves only this : that there is a 
necessary connexion between the idea of every mind and the idca of God,- - no mind can define itself except in terms of God. The argument to the actual reality of God is then completed by resorting to each mind's certainty of its own actual existence through dialectic verification: to attempt to posit the contrary, only ends in positing the self again. From this the actual existence of God follows, because the ectual existence of the self must carry the existence of whatever the idea of the self synthetically involves. I can hardly imagine how my reviewer can heve read pp. $356-359$ of my book, and still say that I make no attempt to prove the actual existence of God as the ideal Type of all the really possible spirits ; nor how he can still set it down that I assume the idesl Type to be one of the series of really possible beings, " and consequently that a being exists who realises the Type".

II.

But enough of these misspprehensions. I must now turn to sundry difficulties that $\mathrm{Mr}$. MeTaggart finds with some of the cardinal conceptions in the theory which my book illustretes, or else with my method of advocating them.

(1) He complains that after going closely with Kant to a certsin point, I then suddenly separate mysalf,_- "abruptly," as be says. By this he sppears to mean my rejection of Kant's restriotion of all our cognition to phenomena and denial of our power to know noumene. He implies that I nowhere give any reasons for rejecting Kant's criticiams on the Paralogism of Pure Reason, but go on to maintain that Pure Resson can know that the self exists, and exists eternally, simply ignoring these colebrated criticisms. It is a fact, of course, that I have not felt it needful to reply in detail to the various branches of Kant's agnostio doctrine, and espeoially not to his essault upon the possibility of proving theoretically the freedom and the immortality of the self. I have chosen to rely, rather, on a general refutation of the agnostic motif, which I hove sapplied in my first essey; and I have relied more especially on the self-refutation of Kantian agnosticism by its own inner dialectical dissolution, which I have traced out in the fourth part of my third essay. These very essential parts of my general ergumentation, my reviewer sppears to have quite overlooked. No reader who omits them will properly understand the argumentative procedure on which I rest my case in the seven essays taken together.

Besides, I hs ve throughout assumed readers will see that Kant's agnostic rustrictions are anticipated, provided for, and rendered inapplicable by the plain implications of the fact of a priori cognition itself, when that is once clearly establisbed and clesrly understood; and this fact I bave explicitly argued out, in two different places in my volume-in the first essay, and again in the sirth. Then. 
too, I have relied on the plain force of the essentially social nature of the self-defining consciousness to lead my resders to see how irrelevant Kant's agnostic tenete are. (See, particularly, my pp. 351-353, and cf. pp. 173-175.) That is to say, the Kantian agnostioism is annulled, so far at least as concerns the certainty of the existence, even the noumenal or eternal existence, of the self. In fact, however. my reviewer is a trifle out in saying I depart from Kant on this point, for Kant himself never supposed that this was unknown or unknowable: what was unknowable was, not the existence, but the nature of the noumenon. If nowhere else, then at all events in the Prolegomsna, Kant declares unmistakably that the existence of selves as Dinge an sich is a known certainty. "That there are no Dinge an sich," he says in substance, "is absurd ". (Cf. the Prolegomena passim, but especially in \$57.)

(2) A more serious complaint is that which Mr. MoTeggart makes that my reasons for treating the Categories as applicable to the self, when I refuse to describe it in terms of Sense Forms, are " not brought out anywhere in the book". This fanlt, if it is a fault, I have to confess. Within the limits of the brief volume I could not compress everything pertaining to a complete vindica. tion of my general view. In particular, Mr. MoTaggart's centrally pertinent question-Why are not the Categories in exactly the same position as Time, as to being necessarily trascended by the noumenal self ? - could only be answered after a complete re-exarnination, going to the foundations, of the whole problem of epistemology. This would need to be taken ap along Kant's own lines, and followed to the point where (at the end of the Transcendental Aralytic) one gets int the position to show that, and just why, Kant has failed to establish the objective character of even natural scienoe. It would then appear that, in order to give really objective value to a priori syntheses in Space and Time, we must combine a pure use of the Categories-a use unmixed with Sense Forms-with their use as "sohemetised " with the help of these Forms. Thus we should learn that there is no possible escape from the transcendent use of the Categories even when we attempt to employ them only transcendentally.

But not only did I feel that this epistemological inquiry was at once too long and too subtle for the publio to which I chiefly addressed my book ; I was also, in the case of more expert readers, relying upon a previous warning as to the general path the inquiry must follow, which I had given in my contribution to the volume entitled The Conception of God, at pp. 124-127. Still, Mr. McTaggart is quite right in pointing out that all this needs to be done in full detail before one can clain to have made a proof of Personal Idealiam clear of all queries. And this I hope some day yet to sacomplish.

(3) My reviewer finds a "weskness" in that part of my argument concerning the existence of God which aims at showing God's Boleness (monotheism), in opposition to the charge of "polytheism" 
or "apeirotheism" urged against my proposition that all selves coexist with God in eternity. He thinks the argument assumes "that beings who are equally perfect could not be different from one another". But it does not assume this; as I have already shown above, when clearing up the misapprehension about perfection and imperfection as applicable to the selves other than God. It does assume, however, that no beings who are absolutely perfect can be different, that is, none that are perfect without immirture of imperfection, and that are wholly supratemporal in their being. The conjunction of this unmixed perfection with eternity is what constitutes the proof for the soleness of God. Mr. MoTaggart fails to get the force of it, I think, because he silently omits this divine differentia before the word "perfect" as I use it of God. And thus contrasting God and other selves as the Perfect and the unrelieved imperfect, he draws the unwarrantable conclusion about "superiority" and "inferiority" which he seems to dislike. But I intend no relation of this sort between God and the souls. They are different, and unchangeably different; they are even different in species, God being perfection eternally fulfilled, the other selves having a time-world of unfulfilment and having to carry it on toward the gosl of fulfilment evermore. Thus the difference between them is in this reference permanent,- - to answer my reviewer's question on this point.

(4) Finally, Mr. McTaggart objects to my calling this sole mind possessing absolute and eternal perfection God. $\mathrm{He}$ insists that the traditional usage shall be absolutely venerated, which makes God the name of one only self-existent Being, who brings all other beings into existence by creation ex nihilo. Here I am quite unable to agree with him. I not only do not think that this solitude of self-existence, conjoined with this universal efficient causality, is the central and essentisl thing in the traditional religious thought of Christendom, but $I$ am sure that the most spiritually minded Christians would at once declare that it is not such; they would say, on the contrary, that the essential thing in the being of God is his holiness, justice, and infinite love. Now, what I point out is, not only that the function of creation, taken literally, is unessential to this moral perfection of God, but that it is in hopeless contradiction with it; and that the obscurely felt fact of this contradiction, a feeling growing ever more clear as the Christian consciousness grows more sure of itself, is at the bottonn of all that restlessness in the region of Christian theology which we all know so well, and which is the characteristic fact in the later Christisn world.

To remove the name of God from the clarified and purified conception of the eternsl Ideal Type, would be to do violence, inexousable atront, to the deepest and truest element in the historic religious consciousness. I feel the strongest assurance that my new interpretation of the name of God is the genuine fulflment of the highest and profoundest prescience in the historic religious 
234 G. H. HOWIBON : IN THE MATTBR OF PRESONAL IDBATIBM.

life. What offends as in the Bpinosistio or other monistio appropristions of the name Gad is the evident absence from their Absolute of all the essential moral qualities. In thase it is that true Deity lies; and all God's metaphysical attributes must be keyed up to them; not one of these "netural " attributes dare be construed in eny way that conflicts with the eternal moral essence. If they have been so construed historically (as indeed they have), genuine theology requires that God's conception shall be relieved of these errors, in order that his true nature may stand revealed as it is.

G. H. Howrsor. 